\title{
EDUCATION AND ECONOMIC GROWTH IN DEVELOPING COUNTRIES: EMPIRICAL EVIDENCE FROM GMM ESTIMATORS FOR DYNAMIC PANEL DATA
}

\author{
Wafa SEBKI \\ University of Abou Bakr Belkaid, Tlemcen, Algeria \\ Corresponding author e-mail: wafa.s.1@hotmail.com
}

\begin{abstract}
The paper aims at studying the effect of education measured by enrolment ratios in secondary and higher education on economic growth measured by the rate of GDP growth in a sample of 40 developing countries during the period from 2002 to 2016 using the dynamic panel data estimators. The results of estimating the model of this study using the difference GMM estimator or what is known as the Arellano and Bond estimator showed that the proportions of those enrolled in tertiary education had a significant positive effect on economic growth, while the proportions of those enrolled in secondary education had a significant negative effect.
\end{abstract}

Keywords: Developing countries; Economic growth; Education; Human capital; Panel data.

JEL Classification: I20; O40; C33

\section{INTRODUCTION}

The interest of economic theory in human capital issues is ancient, but this interest took a new dimension after the second World War, especially after it became clear that not all of the economic growth produced could be justified by the traditional production factors like labour and capital, but it went beyond considering the investment in human capital as an important factor in the formation of production, which was interpreted by many economists such as Solow (1957), Schultz (1961), Becker (1964) and others.

Education at its various levels is considered one of the most effective means of achieving real development of human capital, as it is one of the essential elements of sustainable development and the improvement of human well-being. According to Schultz (1961), the latter represents the most important form of investment in human capital, rather it represents human capital itself because it explains most of the changes and differences in gross national income.

Given the strong positive relationship between education and access to higher levels of economic growth, developing countries have put education at the forefront of their concerns and have attempted to implement a set of policies to increase the stock of their educational capital. Therefore, enrolment rates in primary education improved significantly, moving in the category of low-income countries from $78 \%$ 
in 1999 (UNESCO, 2015) to $103 \%$ in 2015 (UNESCO, 2017), while the total number of enrolments in secondary education also witnessed a remarkable development from 26911000 in 1999 (UNESCO, 2015) to 35274000 in 2015 (UNESCO, 2017), while the total enrolment rate in higher education increased in the same category of countries from $3 \%$ in 2000 to $8 \%$ in 2015 (UNESCO, 2017).

Taking into account the above-mentioned considerations, the following research question can be formulated:

Does education increase economic growth rates in developing countries?

To answer the question above, the following hypothesis is put forward:

H1. Education positively affects economic growth in developing countries.

This research paper highlights the impact of education on economic growth in developing countries. The objectives of the study are to clarify the mechanisms by which education sector affects economic growth and to provide suggestions and recommendations that contribute to the development of investment in human capital in developing countries.

\section{LITERATURE REVIEW}

Human resources are considered one of the most important productive elements that contribute to economic growth, but the latter will not play this role without education, because education contributes to the accumulation of human capital. Therefore, the most important channels through which education affects economic growth can be represented through the scheme below.

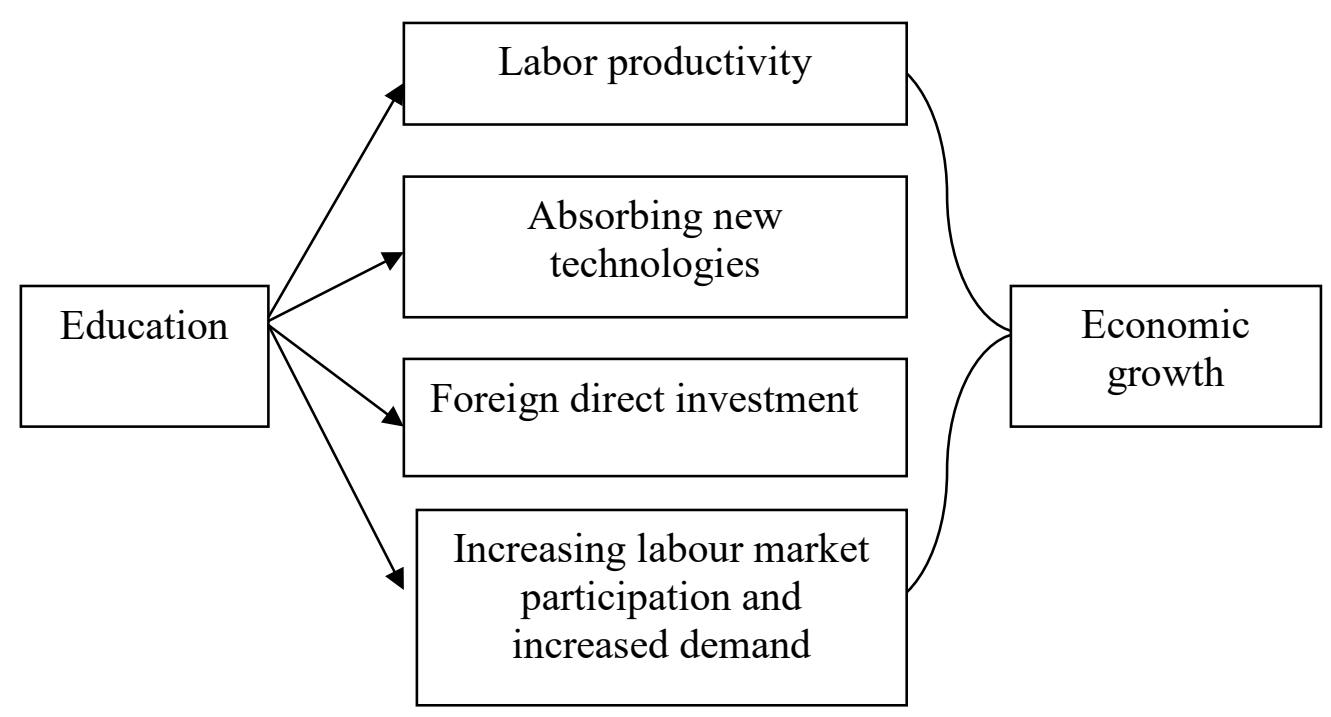

Fig. 1. The channels through which education affects economic growth (Pribac \& Anghelina, 2015). 


\subsection{The Impact of Education on Productivity}

Education as a producer of human capital is one of the decisive factors for productivity growth, as the human capital theory that emerged in the early sixties of the last century mentions that the latter is one of the principal explanatory factors for economic growth through increasing both the quality of the workforce and the production capacity (Ping, 2005). Accordingly, and in general, education increases the labour productivity through the following (Ellery, Paes de Barros \& Grosner, 2013):

- first and foremost, more education involves more information and therefore superior skills to perform specific activities;

- the educated worker is able to perform many activities in less time, and is also able to perform all activities with greater accuracy;

- educated workers are more capable of learning modern activities and are able to integrate management or production mechanisms more easily, as it helps them acquire new technical, managerial and technological skills, as well as the cost of training decreases with the level of education;

- finally, additional education implies an additional capacity to process information, and therefore education is associated with the capacity to make best decisions, especially in an unstable environment.

\subsection{Education and Technology}

Education has an important impact on the speed of catching up with advanced technology, because it facilitates the nation's ability to absorb modern technologies from different states and determines the nation's capacity to innovate locally.

Therefore, if deficiency in material capital can restrict technical development, the presence of well-literate population means that the nation has the capacity to employ or create new technologies (Ping, 2005).

\subsection{Education and Foreign Direct Investment}

More educated workforce is one factor in attracting new foreign direct investment (Pribac \& Anghelina, 2015), which in turn contributes to gross fixed capital formation.

\subsection{Education and Employment}

The higher educational level increases participation rates in the labour market and gives individuals an opportunity to obtain higher income and thus increases the demand for goods and services. According to statistics provided by several international organisations (World Bank, Eurostat), the level of higher education increases the job opportunities. This is explained by the fact that a more prepared and educated individual will enjoy higher productivity, will adapt more to the changes and requirements of globalization, develop new technologies, and be able to acquire new skills more easily. 
Thus, well-equipped and skilled workforce helps increase work efficiency in any field; this supports economic growth and economic development (Aceleanu, 2012).

\section{EMPIRICAL REVIEW}

Among the most important previous studies, the author mentions the following.

Table 1. Summary of Empirical Studies

\begin{tabular}{|c|c|c|c|c|}
\hline Author & Period & Sample & $\begin{array}{c}\text { Econometric } \\
\text { approach }\end{array}$ & Result \\
\hline $\begin{array}{l}\text { Karaçor, Güvenek, } \\
\text { Ekinci, \& Konya } \\
(2017)\end{array}$ & 1998-2012 & $\begin{array}{l}19 \text { of OECD } \\
\text { countries }\end{array}$ & $\begin{array}{l}\text { Fixed effect } \\
\text { model }\end{array}$ & $\begin{array}{l}\text { Education expenditures had no } \\
\text { impact on economic growth }\end{array}$ \\
\hline $\begin{array}{l}\text { Hanif \& Arshed } \\
(2016)\end{array}$ & $1960-2013$ & $\begin{array}{l}5 \text { SAARC } \\
\text { countries }\end{array}$ & $\begin{array}{l}\text { FMOLS } \\
\text { estimator }\end{array}$ & $\begin{array}{l}\text { The results of the study revealed } \\
\text { that enrolment in primary } \\
\text { education had a negative impact on } \\
\text { economic growth, but the effect } \\
\text { was positive for secondary and } \\
\text { tertiary education }\end{array}$ \\
\hline $\begin{array}{l}\text { Eggoh, Houeninvo, } \\
\& \text { Sossou }(2015)\end{array}$ & 1996-2010 & $\begin{array}{l}49 \text { African } \\
\text { countries }\end{array}$ & $\begin{array}{l}\text { OLS and } \\
\text { GMM } \\
\text { estimators }\end{array}$ & $\begin{array}{l}\text { The study concluded that education } \\
\text { and health spending had a negative } \\
\text { impact on economic growth }\end{array}$ \\
\hline Cooray (2009) & 1999-2005 & $\begin{array}{l}46 \text { low and } \\
\text { middle } \\
\text { income } \\
\text { countries }\end{array}$ & $\begin{array}{l}\text { OLS and } \\
\text { GMM } \\
\text { estimators }\end{array}$ & $\begin{array}{l}\text { This research found that there was } \\
\text { a significant positive impact for } \\
\text { each of the ratios of enrolled in } \\
\text { primary, tertiary and secondary } \\
\text { education on economic growth, } \\
\text { and it was also concluded that } \\
\text { government spending had an } \\
\text { indirect impact on economic } \\
\text { growth through its impact on the } \\
\text { quality of education, which in turn } \\
\text { led to improvement of economic } \\
\text { growth rates }\end{array}$ \\
\hline $\begin{array}{l}\text { Ogundari \& } \\
\text { Awokuse (2018) }\end{array}$ & 1980-2008 & $\begin{array}{l}35 \text { sub- } \\
\text { Saharan } \\
\text { African } \\
\text { countries }\end{array}$ & $\begin{array}{l}\text { GMM } \\
\text { estimator }\end{array}$ & $\begin{array}{l}\text { The results showed that each of the } \\
\text { ratios of those enrolled in primary } \\
\text { education, the ratios of those } \\
\text { enrolled in secondary education } \\
\text { and the average years of schooling } \\
\text { had a significant positive impact on } \\
\text { economic growth. Whereas the } \\
\text { proportions of those enrolled in } \\
\text { higher education and spending on } \\
\text { education had an unimportant } \\
\text { effect. As for health indicators, the } \\
\text { latter had a relatively significant } \\
\text { positive effect compared to the } \\
\text { impact of education on economic } \\
\text { growth }\end{array}$ \\
\hline
\end{tabular}




\begin{tabular}{|c|c|c|c|c|}
\hline Author & Period & Sample & $\begin{array}{c}\text { Econometric } \\
\text { approach }\end{array}$ & Result \\
\hline Goumrhar (2017) & $1985-2010$ & $\begin{array}{l}65 \text { develo- } \\
\text { ping } \\
\text { countries }\end{array}$ & $\begin{array}{l}\text { Static panel } \\
\text { methodology }\end{array}$ & $\begin{array}{l}\text { A significant positive effect of the } \\
\text { average school years was found on } \\
\text { economic growth, while the effect } \\
\text { was negative for the indicator of } \\
\text { inequality in education }\end{array}$ \\
\hline $\begin{array}{l}\text { Abdouni \& } \\
\text { Hanchane (2010) }\end{array}$ & 1982-1997 & $\begin{array}{l}30 \text { develo- } \\
\text { ping } \\
\text { countries }\end{array}$ & $\begin{array}{l}\text { GMM } \\
\text { estimator }\end{array}$ & $\begin{array}{l}\text { The results of the study revealed a } \\
\text { significant positive effect of FDI } \\
\text { on economic growth, while the } \\
\text { human capital had a positive but } \\
\text { not significant impact }\end{array}$ \\
\hline $\begin{array}{l}\text { Acaroğlu \& Altun } \\
\text { Ada (2014) }\end{array}$ & 1990-2011 & $\begin{array}{l}15 \text { countries } \\
\text { from the } \\
\text { Middle East } \\
\text { and North } \\
\text { Africa }\end{array}$ & $\begin{array}{l}\text { Static panel } \\
\text { methodology }\end{array}$ & $\begin{array}{l}\text { The results of the study were the } \\
\text { presence of a significant positive } \\
\text { effect for both the life expectancy } \\
\text { at birth and the primary completion } \\
\text { rate on economic growth, while the } \\
\text { fertility rate and student-teacher } \\
\text { ratios had a significant negative } \\
\text { effect on economic growth, as well } \\
\text { as public spending on health and } \\
\text { public spending on education did } \\
\text { not have a significant effect }\end{array}$ \\
\hline $\begin{array}{l}\text { Lingaraj, Pradeep, } \\
\text { \& Kalandi (2016) }\end{array}$ & 1973-2012 & $\begin{array}{l}14 \text { Asian } \\
\text { countries }\end{array}$ & $\begin{array}{l}\text { FMOLS } \\
\text { method }\end{array}$ & $\begin{array}{l}\text { Education spending had a } \\
\text { significant positive effect on } \\
\text { economic growth in the sample } \\
\text { countries studied }\end{array}$ \\
\hline
\end{tabular}

Source: Prepared by the author based on a group of previous studies.

\section{DATA, MODEL AND METHODOLOGY}

\subsection{Data}

The author of the study utilised a balanced panel dataset covering forty developing countries: Burkina Faso, Chile, El Salvador, Moldova, Rwanda, Bulgaria, Indonesia, Malaysia, Thailand, Iran, Senegal, Nepal, Romania, India, Albania, Tunisia, Colombia, Mexico, Cameroon, Poland, Croatia, Algeria, Lebanon, Jamaica, Hungary, Bangladesh, Uruguay, Northern Macedonia, Cape Verde, Saint Lucia, Serbia, Pakistan, Panama, Sudan, Jordan, Brazil, Niger, Mauritius, Cuba and Burundi during the period 2002-2016, based on the availability of data obtained from the (World Bank, 2019).

\subsection{Model}

To estimate the impact of education on economic growth, the author has relied in this study on a set of explanatory variables based on economic theory and several previous studies. Accordingly, the study model can be written as follows: 
$G D P_{i t}=\alpha_{i}+\beta_{1} S E C_{i t}+\beta_{2} H I G_{i t}+\beta_{3} K_{i t}+\beta_{4} L_{i t}+\beta_{5} G_{i t}+\beta_{6} I N F_{i t}+\varepsilon_{i t}$,

or

$$
G D P_{i t}=\alpha_{i}+\beta X_{i t}+\varepsilon_{i t},
$$

where

$G D P_{i t}$ - real gross domestic product growth rate (\%) in a country $i$ and the period $t$;

$S E C_{i t}$ - enrolment ratios in secondary education in a country $i$ and the period $t$; $H I G_{i t}$ - enrolment ratios in higher education in a country $i$ and the period $t$;

$K_{i t}$ - gross fixed capital formation growth rate (\%) in a country $i$ and the period $t$;

$L_{i t}$ - labour growth rate in a country $i$ and the period $t$;

$G_{i t}$ - general government final consumption expenditure (\% growth) in a country $i$ and the period $t$;

$I N F_{i t}$ - inflation rate in a country $i$ and the period $t$;

$\varepsilon_{i t}$ - the value of the error term in the country $i$ and in the period $t$;

$\alpha$ and $\beta$ - estimated coefficients.

\subsection{Methodology}

The author has employed in this study the generalised method of moment estimators developed for dynamic panel models (the difference GMM and System GMM estimators) that has received increasing attention and obtained great popularity especially in recent years.

The latter was developed by Holtz-Eakin, Newey and Rosen (1988), Arellano and Bond (1991), Arellano and Bover (1995), and Blundell and Bond (1998). It is used in the following situations (Roodman, 2009):

- "large $N$ and small $T$ " - a large number of individuals and short periods of time;

- a linear functional relationship;

- one left-hand-side variable that is dynamic, depending on its own past realizations;

- independent variables that are not strictly exogenous, i.e., they are correlated with past and possibly current realizations of the error;

- fixed individual effects;

- heteroskedasticity and autocorrelation within individuals but not across them.

It should also be noted that the GMM estimator was formally formulated by Hansen (1982), and it was later used extensively for estimating models in the fields of economics and finance.

The latter also offers a computationally appropriate method for obtaining consistent and asymptotically normally distributed estimators and it can be considered to encompass almost all common estimation methods such as maximum likelihood, ordinary last squares (Imbens, 2002). 


\subsubsection{Arellano and Bond Estimator (Difference GMM Estimator)}

It is also called the estimation method using the first differences GMM (Youssef, El-Sheikh, \& Abonazel, 2014), and was first presented by Stephen Bond and Manuel Arellano in 1991.

As shown in Equation (3) and contrary to static panel models, the dependent variable in dynamic panel models is dependent on its own past values (Ganic, 2020), and therefore this led to the correlation problem between the lagged dependent variable $G D P(i, t-1)$ and the country specific effect $\mu_{i}$.

$$
\begin{gathered}
G D P_{i t}=\alpha G D P_{i, t-1}+\beta X_{i t}+\mu_{i}+\varepsilon_{i t}, \\
i=1,2, \ldots, N \text { and } t=1,2, \ldots, T .
\end{gathered}
$$

Therefore, in order to obtain consistent estimates in dynamic panel models, Anderson and Hsiao (1982) proposed first differencing the equation to remove individual effects. As a result, Equation (3) becomes as follows:

$$
\begin{aligned}
& \quad\left(G D P_{i t}-G D P_{i, t-1}\right)=\alpha\left(G D P_{i, t-1}-G D P_{i, t-2}\right)+\beta\left(X_{i t}-X_{i, t-1}\right) \\
& +\left(\varepsilon_{i t}-\varepsilon_{i, t-1}\right) .
\end{aligned}
$$

However, while the Anderson-Hsiao estimator is consistent, Arellano and Bond discuss that the latter failed to take all of the potential orthogonality conditions into account, so the Arellano and Bond estimator differs from the Anderson-Hsiao estimator in that it exploits additional moment restrictions, which expands the set of instruments.

Thus, this approach (Arellano and Bond estimator) used the following moment conditions (Nurnaddia \& Nurhaiza, 2016):

$$
\begin{gathered}
E\left[G D P_{i, t-s}\left(\varepsilon_{i, t}-\varepsilon_{i, t-1}\right)\right]=0 \text { for } s \geq 2, t=3, \ldots, T . \\
E\left[X_{i, t-s}\left(\varepsilon_{i, t}-\varepsilon_{i, t-1}\right)\right]=0 \text { for } s \geq 2, t=3, \ldots, T .
\end{gathered}
$$

Additionally, Arellano and Bond (1991) suggested a two-step GMM estimator. Theoretically, the application of the second step is more efficient in large samples (Nurnaddia \& Nurhaiza, 2016).

\subsubsection{Blundell and Bond Estimator (System GMM Method)}

There are several main reasons for saying that the system GMM estimator gives more accurate and efficient results compared to the results of the difference GMM estimator, the most important of which are:

- first, the system GMM allows for more instruments and is able to greatly improve the efficiency compared to the difference GMM estimator (Piper, 2014);

- second, the difference GMM estimator expands the gaps in the unbalanced panels, so that if some value of $Y_{i t}$ is missing, $\Delta Y_{i t}$ and $\Delta Y_{i, t-1}$ will be also missing in the transformed data (Baum, 2013), which leads to the creation and development of the system GMM. 
Therefore, to address the aforementioned deficiencies in the Arellano and Bond estimator, researchers Blundell and Bond (1998) suggest a system GMM method that uses an additional set of moment conditions (Nurnaddia \& Nurhaiza, 2016):

$$
\begin{gathered}
E\left[\left(G D P_{i, t-s}-G D P_{i, t-s-1}\right)\left(\mu_{i}-\varepsilon_{i, t}\right)\right]=0 \text { for } s=1 . \\
E\left[\left(X_{i, t-s}-X_{i, t-s-1}\right)\left(\mu_{i}-\varepsilon_{i, t}\right)\right]=0 \text { for } s=1 .
\end{gathered}
$$

The GMM method is based on the validity of the assumption that the residuals are not serially correlated and on the validity of the instruments. Therefore, these two tests are used:

- first, the Sargan-Hansen test of over-identifying tests for joint validity of the instruments (Sadni Jallab, Gbakou, \& Sandretto, 2008), so that we say that there are no correlations between instruments and residuals when the null hypothesis is accepted (Freimane \& Bālin,a, 2016);

- second, the second-order serial correlation test, where the null hypothesis states that the residuals are not serially correlated, and, therefore, if the null hypothesis is accepted, then there is no secondorder serial correlation and that the GMM estimator is consistent (Hou \& Chen, 2013).

\section{RESULTS AND DISCUSSION}

\subsection{Descriptive Statistics}

The results are summarised in the table below.

Table 2. Summary of Descriptive Statistics

\begin{tabular}{|l|l|l|l|l|l|}
\hline \multicolumn{1}{|c|}{ Variables } & \multicolumn{1}{c|}{ Mean } & \multicolumn{1}{c|}{ Median } & \multicolumn{1}{c|}{ Sd } & \multicolumn{1}{c|}{ Min } & \multicolumn{1}{c|}{ Max } \\
\hline$G D P$ & 4.0493 & 4.1741 & 3.0248 & -7.7320 & 15.1707 \\
\hline$S E C$ & 73.4787 & 82.3548 & 25.9621 & 6.6191 & 120.6316 \\
\hline$H I G$ & 31.7632 & 30.8315 & 20.8296 & 0.8053 & 117.1008 \\
\hline$K$ & 6.0774 & 5.8984 & 10.6744 & -35.8234 & 59.5108 \\
\hline$L$ & 1.6640 & 1.8438 & 1.8801 & -9.9578 & 8.2636 \\
\hline$G$ & 4.5311 & 3.7860 & 6.2907 & -26.3595 & 48.3239 \\
\hline$I N F$ & 5.2614 & 4.1764 & 5.1205 & -3.7 & 39.2660 \\
\hline
\end{tabular}

Source: The author's calculations based on STATA program 2014.

The variability in the distributions is recorded by the standard deviation in Table 2. The results are as follows: economic growth (3.02\%), enrolment ratios in secondary education $(25.96 \%)$, enrolment ratios in higher education $(20.83 \%)$, inflation rate $(5.12 \%)$. These values are widely scattered around the centres and below the mean values, indicating that there are not large variations among the data over time in each distribution, while the standard deviations are for gross fixed capital formation growth rate, labour growth rate and the general government final 
consumption expenditure (\% growth) $10.67 \%, 1.88 \%$ and $6.29 \%$, respectively, which are larger than the mean values.

\subsection{Correlation Matrix Between Model Variables}

The results are summarised in the Table 3 below.

Table 3. Correlation Matrix

\begin{tabular}{|l|l|l|l|l|l|l|l|}
\hline & \multicolumn{1}{|c|}{ GDP } & \multicolumn{1}{c|}{ SEC } & \multicolumn{1}{c|}{ K } & \multicolumn{1}{c|}{ L } & G & INF & HIG \\
\hline$G D P$ & 1.0000 & & & & & & \\
\hline$S E C$ & -0.2560 & 1.0000 & & & & & \\
\hline$K$ & 0.6002 & -0.1395 & 1.0000 & & & & \\
\hline$L$ & 0.1623 & -0.3683 & 0.0898 & 1.0000 & & & \\
\hline$G$ & 0.1714 & -0.2941 & 0.1074 & 0.2045 & 1.0000 & & \\
\hline$I N F$ & -0.0008 & -0.0765 & 0.0207 & -0.0839 & 0.0725 & 1.0000 & \\
\hline$H I G$ & -0.1849 & 0.7672 & -0.1276 & -0.3347 & -0.2832 & -0.0938 & 1.0000 \\
\hline
\end{tabular}

Source: The author's calculations based on STATA program 2014.

In Table 3, we note that there is a positive relationship with statistical significance between gross domestic product and $K$, where the correlation coefficient is estimated at 0.6002 .

We also note that the rate of GDP growth is positively but weakly associated with both the labour growth rate and the general government final consumption expenditure (\% growth), so that the correlation coefficients obtained between gross domestic product and these explanatory variables are estimated at 0.1623 and 0.1714 , respectively.

The rate of GDP growth is negatively and weakly associated with enrolment ratios in secondary education, enrolment ratios in higher education and the inflation rate, as the correlation coefficients between the dependent variable and each of these explanatory variables are estimated at $-0.2560,-0.1849$ and -0.0008 , respectively.

\subsection{Estimation Results of Dynamic Panel Data Estimators}

The results are summarised in the Table 4 below.

Table 4. Estimation Results of Dynamic Panel Data Estimators

\begin{tabular}{|c|c|c|c|c|c|c|}
\hline \multicolumn{6}{|c|}{ Dependent variable: Real gross domestic product growth rate $(\%)$} & \\
\hline Variables & $\begin{array}{l}\text { Pooled } \\
\text { OLS }\end{array}$ & $\begin{array}{l}\text { Fixed } \\
\text { effect }\end{array}$ & $\begin{array}{c}\text { One step } \\
\text { diff GMM }\end{array}$ & $\begin{array}{c}\text { Twostep } \\
\text { diff GMM }\end{array}$ & $\begin{array}{c}\text { One step } \\
\text { sys GMM }\end{array}$ & $\begin{array}{c}\text { Twostep } \\
\text { sys GMM }\end{array}$ \\
\hline 1. $G D P$ & $\begin{array}{l}0.2925 \\
(7.08)^{* * *}\end{array}$ & $\begin{array}{l}0.1185 \\
(2.01)^{*}\end{array}$ & $\begin{array}{l}0.2525 \\
(2.31)^{* *}\end{array}$ & $\begin{array}{l}0.2204 \\
(2.20)^{* *}\end{array}$ & $\begin{array}{l}0.2762 \\
(2.80)^{* * *}\end{array}$ & $\begin{array}{l}0.2854 \\
(2.62)^{* *}\end{array}$ \\
\hline SEC & -0.01634 & 0.01199 & -0.0249 & -0.0479 & -0.0242 & -0.0274 \\
\hline
\end{tabular}




\begin{tabular}{|c|c|c|c|c|c|c|}
\hline \multicolumn{7}{|c|}{ Dependent variable: Real gross domestic product growth rate (\%) } \\
\hline$N=\mathbf{4 0}$ & & $T=15$ & & & & \\
\hline \multirow[t]{2}{*}{ Variables } & $\begin{array}{l}\text { Pooled } \\
\text { OLS }\end{array}$ & $\begin{array}{l}\text { Fixed } \\
\text { effect }\end{array}$ & $\begin{array}{c}\text { One step } \\
\text { diff GMM }\end{array}$ & $\begin{array}{c}\text { Twostep } \\
\text { diff GMM }\end{array}$ & $\begin{array}{c}\text { One step } \\
\text { sys GMM }\end{array}$ & $\begin{array}{c}\text { Twostep } \\
\text { sys GMM }\end{array}$ \\
\hline & $(-2.54)^{* *}$ & $(0.91)$ & $(-0.92)$ & $(-2.37)^{* *}$ & $(-1.58)$ & $(-2.16)^{* *}$ \\
\hline K & $\begin{array}{l}0.1201 \\
(10.08)^{* * *}\end{array}$ & $\begin{array}{l}0.1195 \\
(10.39)^{* * *}\end{array}$ & $\begin{array}{l}0.1208 \\
(7.63)^{* * *}\end{array}$ & $\begin{array}{l}0.1242 \\
(8.66)^{* * *}\end{array}$ & $\begin{array}{l}0.1172 \\
(8.46)^{* * *}\end{array}$ & $\begin{array}{l}0.1162 \\
(11.23)^{* * *}\end{array}$ \\
\hline$L$ & $\begin{array}{l}0.056 \\
(0.91)\end{array}$ & $\begin{array}{l}0.0849 \\
(0.96)\end{array}$ & $\begin{array}{l}0.0374 \\
(0.35)\end{array}$ & $\begin{array}{l}0.0102 \\
(0.09)\end{array}$ & $\begin{array}{l}0.0803 \\
(0.87)\end{array}$ & $\begin{array}{l}0.0947 \\
(1.01)\end{array}$ \\
\hline$G$ & $\begin{array}{l}0.01934 \\
(1.08)\end{array}$ & $\begin{array}{l}0.031 \\
(1.75)^{*}\end{array}$ & $\begin{array}{l}0.0302 \\
(1.25)\end{array}$ & $\begin{array}{l}0.0391 \\
(1.73)^{*}\end{array}$ & $\begin{array}{l}0.0278 \\
(1.26)\end{array}$ & $\begin{array}{l}0.0465 \\
(1.90)^{*}\end{array}$ \\
\hline INF & $\begin{array}{l}-0.0083 \\
(-0.37)\end{array}$ & $\begin{array}{l}-0.067 \\
(-1.96)^{*}\end{array}$ & $\begin{array}{l}-0.0768 \\
(-1.23)\end{array}$ & $\begin{array}{l}-0.0617 \\
(-0.77)\end{array}$ & $\begin{array}{l}0.0771 \\
(-1.46)\end{array}$ & $\begin{array}{l}-0.0357 \\
(-0.56)\end{array}$ \\
\hline$H I G$ & $\begin{array}{l}0.0084 \\
(1.16)\end{array}$ & $\begin{array}{l}-0.0071 \\
(-0.47)\end{array}$ & $\begin{array}{l}0.0468 \\
(0.87)\end{array}$ & $\begin{array}{l}0.0539 \\
(1.95)^{*}\end{array}$ & $\begin{array}{l}0.02 \\
(0.99)\end{array}$ & $\begin{array}{l}0.0269 \\
(2.32)^{* *}\end{array}$ \\
\hline Constant & $\begin{array}{l}4.1825 \\
(8.19)^{* * *}\end{array}$ & $\begin{array}{l}2.2916 \\
(1.58)\end{array}$ & - & - & $\begin{array}{l}2.8233 \\
(2.75)^{* * *}\end{array}$ & $\begin{array}{l}2.9273 \\
(2.22)^{* *}\end{array}$ \\
\hline $\begin{array}{l}\text { Years } \\
\text { dummies }\end{array}$ & Yes & Yes & Yes & Yes & Yes & Yes \\
\hline$N$ of OBS & 560 & 560 & 520 & 520 & 560 & 560 \\
\hline$F$ statistic & 22.81 & 35.63 & 28.90 & 32.36 & 24.63 & 44.13 \\
\hline $\begin{array}{l}\text { Groups/ } \\
\text { instruments }\end{array}$ & - & - & $40 / 28$ & $40 / 28$ & $40 / 34$ & $40 / 34$ \\
\hline $\operatorname{AR}(2)$ & - & - & 0.356 & 0.353 & 0.351 & 0.352 \\
\hline $\begin{array}{l}\text { Hansen } \\
\text { statistic }\end{array}$ & - & - & 0.376 & 0.376 & 0.363 & 0.363 \\
\hline
\end{tabular}

Source: The author's calculations based on STATA program 2014.

Note: Xtabond2 is the syntax used to get the GMM estimates in the STATA program.

*** Indicate significance at the level $1 \%$.

** Indicate significance at the level $5 \%$.

* Indicate significance at the level $10 \%$.

\subsection{How to Decide Between Difference and System GMM Estimators}

To choose between difference GMM and system GMM estimators, according to Bond et al. (2001), the following steps should be followed (Presbitero, 2006):

- The autoregressive model should be initially estimated by pooled OLS and fixed effect (FE) approach;

- The coefficient of the lagged dependent variable $\varphi$ estimated by the pooled OLS must be considered an upper-bond estimate, whereas the corresponding FE estimate must be considered a lower bond estimate;

- If the difference GMM estimate acquired is close to or below the FE estimate, in this case the system GMM estimator must be preferred.

In Table 4, the value of $\varphi$ estimated using the difference GMM estimator (0.2204) is close to the value of the same coefficient estimated using the OLS methodology (0.2925). Therefore, the difference GMM estimator (two-step 
difference GMM is more effective than the one-step difference GMM) is appropriate for the data of this study.

\subsection{Validity Tests of Two-Step Difference GMM Estimator}

As a two-step difference GMM estimator is appropriate for this study, its validity will be verified through the following:

- $\varphi$ estimated using the two-step difference GMM lie in-between the FE coefficient and the POLS coefficient $(0.1185<0.2204<0.2925)$, indicating the validity of the dynamic panel estimator used.

- The results of the difference GMM estimations also indicate the significance of $\varphi$, which indicates that the GDP was directly affected by its value in the previous period, which reflects the suitability of the dynamic estimator used.

- The insignificant probability value of the $\operatorname{AR}(2)$ test $(\operatorname{AR}(2)=0.353)$ reveals the absence of second order serial autocorrelation and the Hansen $J$-statistic for overidentifying restrictions (Hansen statistic $=0.376)$ indicating that our instruments for both GMM models are valid.

- On the other hand, most of the two-step difference GMM coefficients are significant.

- This study includes 40 countries which were analysed over a period of 15 years $(T)$. Therefore, there are more countries $(N)$ compared to years $(T)$, and the number of groups is greater than the number of instruments $(40>28)$.

Judging from previous diagnostic tests, it can be said that the two-step difference GMM estimator is a valid estimator.

\subsection{Long-Run Effect of Determinants of Economic Growth and Interpretation of Results}

Papke and Wooldridge (2004) explained a method for computing the standard error and long-term coefficients in a dynamic panel data model. To obtain them, it is necessary to use "nlcom" command in the STATA program (Nurnaddia \& Nurhaiza, 2016).

Table 5. Long-Run Effect of Determinants of Economic Growth

\begin{tabular}{|l|c|c|}
\hline \multicolumn{3}{|c|}{ Dependent variable: Real GDP growth rate (\%) } \\
\hline $\begin{array}{c}\text { The nature of the independent } \\
\text { variable }\end{array}$ & Long-run coefficient value & $\begin{array}{c}\text { The } \boldsymbol{P} \text {-value of the } \\
\boldsymbol{Z} \text {-statistic }\end{array}$ \\
\hline$S E C$ & -0.0614 & 0.014 \\
\hline$K$ & 0.1593 & 0.000 \\
\hline$L$ & 0.0131 & 0.929 \\
\hline$G$ & 0.0502 & 0.121 \\
\hline$I N F$ & -0.0791 & 0.447 \\
\hline$H I G$ & 0.0691 & 0.043 \\
\hline
\end{tabular}

Source: The author's calculations based on STATA program 2014. 
Regarding the coefficient of enrolment ratios in secondary education, it appeared negatively and significantly in the long and short term and this result was consistent with many previous studies, such as (Gökhan, 2015). However, it is inconsistent with economic theory and with the results of studies indicating the positive impact of human capital as measured by secondary education on economic growth (e.g., (Hanif \& Arshed, 2016; Ogundari \& Awokuse, 2018; Ogunleye, Owolabi, Sanyaolu \& Lawal, 2017)). This negative impact in the short term can be explained by the fact that the increasing percentage of students enrolled in secondary education costs the state large sums (a burden on the state), while the negative impact in the long run is explained by the fact that this group (especially those that have not enrolled in higher education) lacks the skills and experience that are needed by the labour markets in developing countries.

As for the coefficient of the fixed capital formation, it appeared positive and significant in the short and the long term, which was consistent with economic theory and a set of previous experimental studies (Anupam \& Biru, 2011; Bonnefond, 2014). Increasing this indicator by $1 \%$ leads to an increase in economic growth rates of $0.1593 \%$ in the long term, which confirms its pivotal role in the growth process.

The employment growth coefficient appeared positive but not significant in the short and long term. It means that the increase in employment rates has no effect on economic growth in the sample of developing countries selected in the study, which is a similar result to the findings of Anupam and Biru (2011). In contrast, the study by Liming (2014) found that labour force participation rates are insufficient to support economic growth in a sample of 284 Chinese prefecture cities. In addition, others have found a negative and insignificant relationship between the workforce and economic growth (Girgin, Nguyen \& Karlis, 2017).

Regarding the coefficient of the general government final consumption expenditure, it appeared positive and significant in the short term, while it appeared positive and not significant in the long term, and this could be attributed to the weakness of the adopted financial policy in developing countries. Our results are inconsistent with studies (Kimaro, Keong \& Sea, 2017), which found a positive and significant relationship between government spending and economic growth, while other studies (Sezer \& Abasiz, 2016) found a negative and significant relationship between them.

The presence of a negative and non-significant effect of inflation rates on economic growth means the absence of the effect of inflation on economic growth in the sample of developing countries selected in the study. Therefore, our results are inconsistent with studies (e.g., Lenka \& Sharma, 2014; Trpkova \& Tashevska, 2011) that found a negative and significant relationship between the two variables.

The coefficient of enrolment ratios in tertiary education appeared positive and significant in the short and long term, which was consistent with economic theory and many previous studies (Cooray, 2009; Ogunleye, Owolabi, Sanyaolu \& Lawal, 2017). However, this effect was somewhat slight, so that an increase in higher education enrolment rates of $1 \%$ leads to increasing economic growth by only $0.0691 \%$ in the long run, which confirms that education in developing countries 
has not yet become the main engine for growth, but is only a factor of growth, possibly because of the following:

- the poor quality of higher education in developing countries, which is also due to the use of traditional teaching methods, a large shortage of experienced teachers;

- mismatch between education and labour market needs in developing countries;

- brain drain from developing countries;

- high unemployment rates among graduates.

\section{CONCLUSION}

The article has presented an econometric study in order to investigate the nature of the relationship between education and economic growth in a sample of developing countries during the period of 2002-2016 based on the dynamic panel estimators. The author of the study has discussed the most important channels through which education affects economic growth, introduced the methodology used in the study by presenting both Arellano and Bond estimator (1991) and Blundell and Bond estimator (1998). Then the author has identified the variables used to estimate the model of this study based on both economic theory and a set of previous studies. At the end of the research, it has been found that the percentage of those enrolled in higher education has a slight positive effect on economic growth, while the effect is negative for the percentage of those enrolled in secondary education.

Based on the results obtained, the following recommendations are made.

- It is necessary to bring about a change in the education system in these countries by reforming educational programmes in line with the requirements of the global economy based on knowledge and technology.

- It is required to pay more attention to the quality of education rather than focus on quantitative expansion.

- It is suggested to benefit from global experiences in the field of human capital development by conducting joint courses.

\section{REFERENCES}

Abdouni, A., \& Hanchane, H. (2010). Investissement Direct Etranger, Capital Humain et Croissance Economique: Etude Empirique en Donnees de Panel. AMSE. Nr. 2010-06.

Acaroğlu, H., \& Altun Ada, A. (2014). The Relation Between Human Capital and Economic Growth in MENA Countries. Journal of Public Administration and Governance, 4(3), 205. https://doi.org/10.5296/jpag.v4i3.6127

Aceleanu, M. I. (2012). Links Between Education, Employment and Quality of Life. The Case of Romania. Management \& Marketing Challenges for the Knowledge Society, 7(4), 717-730.

Anderson, T. W., \& Hsiao, C. (1982). Formulation and Estimation of Dynamic Models using Panel Data. Journal of Econometrics, 18(1), 47-82. https://doi.org/10.1016/0304-4076(82)90095-1

Anupam, D., \& Biru, P. P. (2011). Openness and Growth in Emerging Asian Economies: Evidence from GMM Estimations of a Dynamic Panel. Economics Bulletin, 31(3), 2219-2228. 
Arellano, M., \& Bover, O. (1995). Another Look at the Instrumental Variable Estimation of Error Components Models. Journal of Economics, 68(1), 29-51. https://doi.org/10.1016/03044076(94)01642-D

Arrelano, M., \& Bond, S. (1991). Some Tests of Specification for Panel Data: Monte Carlo Evidence and Application to Employment Equations. Review of Economic Studies, 58(2), 277-297. https://doi.org/10.2307/2297968

Baum, C. F. (2013). Dynamic Panel Data Estimator. Applied Econometrics. Boston College.

Becker, S. G. (1964). Human Capital: A Theoretical and Empirical Analysis, With Special Reference to Education. New York: National Bureau of Economic Research. https://doi.org/10.1177/000271626536000153

Blundell, R., \& Bond, S. (1998). Initial Conditions and Moment Restrictions in Dynamic Panel Data Models. Journal of Economics, 87(1), 115-143. https://doi.org/10.1016/S0304-4076(98)00009-8

Bond, S. R., Hoeffler, A., \& Temple, J. (2001). GMM Estimation of Empirical Growth Models. Retrieved from http://www.nuff.ox.ac.uk/Economics/papers/2001/w21/bht10.pdf

Bonnefond, C. (2014). Growth Dynamics and Conditional Convergence Among Chinese Provinces: A Panel Data Investigation Using System GMM Estimator. Journal of Economic Development, 39(4). https://doi.org/10.35866/caujed.2014.39.4.001

Cooray, A. (2009). The Role of Education in Economic Growth. Asian-Pacific Economic Literature, 23(1), 1-20. http://doi.org/10.1111/j.1467-8411.2009.01220.x

Eggoh, J., Houeninvo, H., \& Sossou, G.-A. (2015). Education, Health and Economic Growth in African Countries. Journal of Economic Development, 40(1), 93-111.

Ellery, R., Paes de Barros, R., \& Grosner, D. (2013). Labor productivity Determinants for the Strategy on Sustainability and Promotion of the Middle Class.

Freimane, R., \& Bālina, S. (2016). Research and Development Expenditures and Economic Growth in the EU: A Panel Data Analysis. Economics and Business, 29, 5-11. https://doi.org/10.1515/eb-2016-0016

Ganic, M. (2020). Are Determinants of International Financial Integration in the European Transition Countries Different from Post-Transition Countries? Studies in Business and Economics, 15(1), 40-54. https://doi.org/10.2478/sbe-2020-0005

Girgin, S. C., Nguyen, H., \& Karlis, T. (2017). Revisiting the Effect of Financial Development on Economic Growth After the 2008 Global Financial Crisis. Advances in Economics and Business, 5(8), 456-465. http://doi.org/10.13189/aeb.2017.050804

Gökhan, U. (2015). Impact of Human Capital on Economic Growth: A Panel Data Analysis.

Goumrhar, H. (2017). Human Capital, Inequality and Economic Growth in Developing countries: Analysis in Panel Data. Int. Journal of Innovation and Applied Studies, 20(2), 441-460.

Hanif, N., \& Arshed, N. (2016). Relationship Between School Education and Economic Growth: SAARC Countries. International Journal of Economics and Financial Issues, 6(1), 294-300.

Hansen, L. P. (1982). Large Sample Properties of Generalized Method of Moments Estimators. Econometrica, 50(04), 1029-1054. https://doi.org/10.2307/1912775

Holtz-Eakin, D., Newey, W., \& Rosen, H. S. (1988). Estimating Vector Autoregressions With Panel Data. Econometrica, 56, 1371-1395. https://doi.org/10.2307/1913103

Hou, N., \& Chen, B. (2013). Military Expenditure and Economic Growth in Developing Countries: Evidence From System GMM Estimates. Defence and peace economics, 24(3), 183-193. https://doi.org/10.1080/10242694.2012.710813

Imbens G. W. (2002). Generalized Method of Moments and Empirical Likelihood. American Statistical Association Journal of Business \& Economic Statistics, 20(4), 493-506. https://doi.org/10.1198/073500102288618630

Karaçor, Z., Güvenek, B., Ekinci, E., \& Konya, S. (2017). Relationship with Education Expenditure and Economic Growth in OECD Countries: A Panel Data Analysis.

Kimaro, E. L., Keong, C. C., \& Sea, L. L. (2017). Government Expenditure, Efficiency and Economic Growth: A Panel Analysis of Sub Saharan African low-income countries. African Journal of Economic Review, 5(2), 34-54.

Lenka, S. K., \& Sharma, P. (2014). FDI as a Main Determinant of Economic Growth: A Panel Data Analysis. Annual Research Journal of SCMS, Prune, 1, 84-97. Retrieved from https://www.scmspune.ac.in/chapter26/7.pdf 
Liming, H. (2014). The Dynamic Relationship Between Real Estate Investment and Economic Growth: Evidence from Prefecture City Panel Data in China. IERI Procedia, 7, 2-7. https://doi.org/10.1016/j.ieri.2014.08.002

Lingaraj, M., Pradeep, K. D., \& Kalandi, C. P. (2016). Impact of Educational Expenditure on Economic Growth in Major Asian Countries: Evidence from Econometric Analysis. Theoretical and Applied Economics, XXIII(607), 173-186.

Nurnaddia, N., \& Nurhaiza, N. (2016). Determinants of Innovation in Developing Countries: A Panel Generalized Method of Moment Analysis. Jurnal Ekonomi Malaysia, 50(2), 93-105. http://dx.doi.org/10.17576/JEM-2016-5002-08

Ogundari, K., \& Awokuse, T. (2018). Human Capital Contribution to Economic Growth in SubSaharan Africa: Does Health Status Matter More Than Education? Economic Analysis and Policy, 58, 131-140. https://doi.org/10.1016/j.eap.2018.02.001

Ogunleye, O., Owolabi, O. A., Sanyaolu, O., \& Lawal, O. (2017). Human Capital Development and Economic Growth in Nigeria. Journal of Business Management, 3(8), 17-37.

Papke, L. E., \& Wooldridge, J. M. (2004). A Computational Trick for Delta Method Standard Errors. Economics Letters, 86(3), 413-417. https://doi.org/10.1016/j.econlet.2004.07.022

Ping, H. (2005). How Does Education at All Levels Influence Productivity Growth? Evidence from the Chinese Provinces. CERDI, working papers. CNRS-Université d'Auvergne.

Piper, A. T. (2014). The Benefits, Challenges and Insights of a Dynamic Panel Assessment of Life Satisfaction. MPRA Paper (59556). Retrieved from https://mpra.ub.unimuenchen.de/id/eprint/59556

Presbitero, A. F. (2006). The Debt-Growth Nexus in Poor Countries: A Reassessment. Economics: The Open-Access, Open-Assessment E-Journal, 2(2008-30), 1-28. https://doi.org/10.5018/economics-ejournal.ja.2008-30

Pribac, L., \& Anghelina, A. (2015). Human Capital -The Effects of Education on Economic Growth Within the European Union. Studia Universitatis "Vasile Goldis" Arad-Economics Series, 25(3), 35-44. https://doi.org/10.1515/sues-2015-0020

Roodman, D. (2009). How to Do Xtabond2: An Introduction to Difference and System GMM in Stata. The Stata Journal, 9(1), 86-136. https://doi.org/10.1177/1536867X0900900106

Sadni-Jallab, M., Gbakou, M., \& Sandretto, R. P. (2008). Foreign Direct Investment, Macroeconomic Instability and Economic Growth in MENA Countries. GATE Working Paper No. 08-17. https://doi.org/10.2139/ssrn.1170764

Schultz, T. W. (1961). Investment in Human Capital. American economic review, 51(1), 1-17.

Sezer, S., \& Abasiz, T. (2016). Determinants of Economic Growth: An Application with Unbalanced Panel Analysis in OECD Countries. The Journal of Visionary, 7(16), 89-99. https://doi.org/10.21076/vizyoner.265474

Solow, M. R. (1957). Technical Change and The Aggregate Production Function. The review of economics and statistics, 39(3), 312-320. https://doi.org/10.2307/1926047

Trpkova, M., \& Tashevska, B. (2011). Determinants of Economic Growth in South - East Europe: A Panel Data Approach. Perspectives of Innovations, Economics and Business, 7(1), 12-15. https://doi.org/10.15208/pieb.2011.03

UNESCO. (2015). Education for All 2000-2015: Achievements and Challenges.

UNESCO. (2017). Accountability in Education: Meeting Our Commitments.

World Bank. (2019). World Development Indicators.

Youssef, A. H., El-Sheikh, A. A., \& Abonazel, M. R. (2014). Improving the Efficiency of GMM Estimators for Dynamic Panel Models. Far East Journal of Theoretical Statistics, 47(2), 171-189. Retrieved from https://mpra.ub.uni-muenchen.de/id/eprint/68675 


\section{AUTHOR'S SHORT BIOGRAPHY}

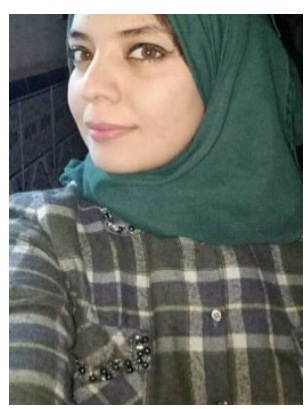

Wafa Sebki obtained a Master degree in Quantitative Economics at Abou Bakr Belkaid University, Algeria, in 2015 and a Ph. D. in the same specialty in 2020. The author has worked as an Assistant Professor at Abou Bakr Belkaid University, Tlemcen - Algeria from 2015. The author is concerned with several economic issues, the most important of which are human capital, unemployment, economic development.

E-mail: wafa.s.1@hotmail.com

ORCID ID: https://orcid.org/0000-0003-3369-9252 